\title{
Net requirements of energy, protein and macrominerals for weight gain of grazing beef cattle castrated at different ages, with and without supplementation ${ }^{1}$
}

\author{
Anilza Andréia da Rocha ${ }^{2}$, Mário Fonseca Paulino ${ }^{3}$, Henrique Jorge Fernandes ${ }^{4}$, Lívia Vieira \\ de Barros ${ }^{2}$, Sidnei Antonio Lopes ${ }^{2}$, Leandro Galon ${ }^{5}$, Aline Gomes da Silva ${ }^{2}$, Daniel Mageste \\ de Almeida ${ }^{2}$
}

\footnotetext{
1 Project financed by Fapemig.

2 Universidade Federal de Viçosa.

${ }^{3}$ Universidade Federal de Viçosa. Researcher from INCT-CA.

${ }^{4}$ Universidade Estadual de Mato Grosso do Sul.

${ }^{5}$ Universidade Federal do Pampa.
}

\begin{abstract}
The objective of this experiment was to estimate the requirements of energy, protein and macrominerals of grazing crossbreds calves, in Brachiaria decumbens Stapf pasture, castrated at different ages, with and without supplementation. Forty-seven young calves at initial age of $120 \pm 30.1$ days and $115.3 \pm 1.97 \mathrm{~kg}$ of live weight were used. To estimate net energy requirements for weight gain, a regression equation between energy retained in the gain and empty body weight gain and metabolic empty body weight was obtained. For estimation of net protein requirements for weight gain, a regression equation was adjusted between protein retained in gain and empty body weight gain and energy content of this gain. Net requirements of Ca, P, Mg and Na for weight gain were determined by the equation $\mathrm{Y}^{\prime}=\mathrm{a} . \mathrm{b}$. $\mathrm{X}^{\mathrm{b}-1}$, in which a and $\mathrm{b}$ represent the intercept and the coefficient of the alometric equation of macromineral body content prediction, respectively. Neither castration nor concentrate supplementation affects body weight gain net requirements, except the ones of Ca, which were higher for non-castrated animals.
\end{abstract}

Key Words: castration, supplementation, Zebu cattle

\section{Introduction}

Cattle production in Brazil is mainly pasture-extensive. However, there is little information on animal requirement in the Brazilian pasture regime (Fontes 1995; Zervoudakis et al, 2002; Fregadolli, 2005; Moraes, 2010). Therefore, it is very important to establish specific feeding patterns for cattle raised in those conditions.

The net energy system, developed by Lofgreen \& Garrett (1968), is the basis of the NRC (2000), a model adopted worldwide for diet formulation for beef cattle (Tedeschi et al., 2002). This system sorts nutritional requirements for maintenance and weight gain (growth and weight gain). Maintenance and gain needs represents the net requirement of the animals. By knowing net requirements, requirements of metabolizable nutrients can be obtained from use efficiency factors of feed energy for maintenance and gain.

According to Paulino et al. (1999), energy value (and even protein value) of body weight gain depends on fat and protein proportion, which are deposited in the body. Therefore, requirements of energy and protein follow those variations in body composition of the animals.
The objective of this study was to evaluate the effect of castration and concentrate supplementation on net requirement for weight gain of male cattle under grazing.

\section{Material and Methods}

The experiment was carried out in Setor de Bovinocultura de Corte in Departamento de Zootecnia at Universidade Federal de Viçosa, from March 2008 to May 2009, totaling 395 days.

At the beginning of the experiment, 47 crossbred calves with at least $50 \%$ of Nellore breed, at average age of $120 \pm 30.1$ days and initial average weight of $115.3 \pm 1.97 \mathrm{~kg}$ were used; all of them suckling by their respective dams. Animals were evaluated during phases of grazing superprecocious calf production: suckling, growth during the dry season and dry-rainy transition periods and finishing during the rainy season. Treatments against ectoparasites and endoparasites were carried out whenever needed.

Three animals were slaughtered at the beginning of the experiment for reference of initial body composition of the 
animals. The 44 remaining animals were randomly distributed into two groups, which were fed concentrate supplementation or only mineral mixture (supplementation systems). In each supplementation group, animals were castrated at 120, 240 and 360 days of age, with average body weight of 115, 175 and $276 \mathrm{~kg}$, respectively, or just not castrated.

After initial weighing, animals were housed in paddocks formed by Brachiaria decumbens Stapf, provided with covered troughs and drinkers. Plots were rotated every 7 days to avoid reduction of possible differences between paddocks.

Supplement was fed daily at around 10:00 a.m. Composition (Table 1) and quantity of the supplement fed varied according to period of the year and animal life phase, to fit the diet to needs predicted by NRC (2000), taking into account a prediction of the composition and pasture availability. In the suckling phase, supplements were supplied at the quantity of $750 \mathrm{~g} / \mathrm{animal} / \mathrm{day}$. In the growth phase, during the dry season, supplements were supplied at the quantity of 1,500 g/animal/day. In the growth phase, during the dry-rainy transition season, supplements were supplied at the quantity of $1,700 \mathrm{~g} / \mathrm{animal} / \mathrm{day}$, and finally, during the finishing phase, supplements were supplied at the amount of 2,000 g/animal/day.

Even with concentrate supplementation, growth and body composition of grazing cattle varied according to season of the year. This variation directly affects nutritional requirement.

To obtain data on growth and body development variation during the experimental period, two intermediate slaughtering processes were carried out before the final experiment slaughter, in representative moments of periods of the year able to cause greater changes. Such procedure allowed obtaining intermediate points in the growth curve of body components, which are important in long-duration experiments, in return to the traditional protocol of evaluating only initial and final body composition of the animals.

Thus, 120 days after the beginning of the experiment, in the early dry season, eight animals were slaughtered, four animals castrated at 120 days of age (two animals from the control treatment and two animals from the supplement with concentrate experiment).

The second slaughter was in October, at the beginning of the dry-rainy season. Twelve animals were slaughtered: two animals castrated at 120 days of age (one from the mineral mixture treatment and another from the one supplemented with concentrate treatment), four animals castrated at 240 days of age (two from mineral mixture treatment and two from the supplement with concentrate treatment) and six non-castrated animals (three from the mineral mixture treatment and three others from the supplement with concentrate treatment).

The third slaughter was performed at the end of the experiment, early May of the following year, during the rainy-dry transition season. At this moment, the 23 remaining animals were slaughtered: six animals castrated at 120 days of age (three from the mineral mixture treatment and three from the supplement with concentrate treatment), seven animals castrated at 240 days of age (three from the mineral mixture treatment and four from the supplement with concentrate treatment), six animals castrated at 360 days of age (three from the mineral mixture treatment and three from the supplement with concentrate treatment) and four non-

Table 1 - Composition of concentrate supplement, pasture and milk consumed by animal in different phases

\begin{tabular}{|c|c|c|c|c|c|c|c|c|c|}
\hline \multirow[t]{2}{*}{ Item } & \multicolumn{3}{|c|}{ Suckling phase } & \multicolumn{2}{|c|}{$\begin{array}{l}\text { Growth phase, during } \\
\text { the dry season }\end{array}$} & \multicolumn{2}{|c|}{$\begin{array}{l}\text { Growth phase, duringdry-rainy } \\
\text { transition season }\end{array}$} & \multicolumn{2}{|c|}{$\begin{array}{l}\text { Finishing } \\
\text { phase }\end{array}$} \\
\hline & Supplement & Pasture $^{2}$ & Milk & Supplement & Pasture $^{2}$ & Supplement & Pasture $^{2}$ & Supplement & Pasture $^{2}$ \\
\hline \multicolumn{10}{|c|}{ Feeds combination (\% MN) } \\
\hline Corn + Sorghum & 62.0 & & & 43.2 & & 53.2 & & 53.2 & \\
\hline Soybean meal & 32.7 & & & 55.1 & & 50.5 & & 50.5 & \\
\hline Mineral mixture ${ }^{1}$ & 5.3 & & & 1.7 & & 6.3 & & 6.3 & \\
\hline \multicolumn{10}{|c|}{ Chemical composition $^{3}$} \\
\hline Dry matter & 87.2 & $22.1 \pm 2.45$ & 13.1 & 87.1 & $21.8 \pm 2.24$ & 87.9 & $28.3 \pm 2.34$ & 87.9 & $28.3 \pm 2.14$ \\
\hline Organic matter & 93.9 & $91.4 \pm 0.21$ & 90.0 & 80.9 & $91.8 \pm 0.15$ & 92.0 & $92.4 \pm 0.33$ & 78.0 & $91.4 \pm 0.16$ \\
\hline Crude protein & 19.9 & $9.3 \pm 0.30$ & 24.9 & 28.9 & $8.1 \pm 0.27$ & 22.9 & $9.7 \pm 0.23$ & 22.9 & $10.1 \pm 0.90$ \\
\hline NDFap & 10.0 & $60.7 \pm 1.10$ & 0.0 & 11.5 & $69.1 \pm 1.04$ & 10.4 & $71.5 \pm 1.06$ & 10.4 & $67.2 \pm 1.20$ \\
\hline iNDF & 1.6 & $16.7 \pm 1.61$ & 0.0 & 1.6 & $18.1 \pm 1.1$ & 1.6 & $20.2 \pm 1.62$ & 1.6 & $16.2 \pm 1.59$ \\
\hline Ether extract & 1.1 & $1.5 \pm 0.10$ & 33.4 & 1.1 & $1.9 \pm 0.56$ & 1.1 & $2.0 \pm 0.3$ & 1.1 & $1.9 \pm 0.16$ \\
\hline
\end{tabular}

NDFap - neutral detergent fiber corrected for ash and protein; iNDF - indigestible neutral detergent fiber.

${ }^{1}$ Percentage composition: dicalcium phosphate - 50.00; sodium chloride - 47.775; zinc sulfate - 1.40; copper sulfate - 0.70 ; cobalt sulfate - 0.05 ; potassium iodate - 0.05 and sodium selenite - 0.025 .

2 Obtained by manual grazing simulation.

${ }^{3}$ Expressed as \% DM, except DM (expressed as \% MN). 
castrated animals (two from the mineral mixture treatment and two animals from the supplement with concentrate treatment).

Before slaughter, all animals were submitted to a 16-hour fast for obtainment of body weight during fasting. After slaughter, gastrointestinal tract of each animal was emptied and washed, and its weight was added to the organs and other body parts (carcass, head, leather, tail, feet and blood) for determination of empty body weight (EBW). The relationship obtained between EBW and body weight (BW) of the animas in each slaughter was used for estimating the EBW of the animals remaining in the experiment.

At slaughter, blood samples were collected after jugular vein section, placed in glass containers and oven-dried ( $60^{\circ} \mathrm{C}, 72$ hours).

Body components industrial meat, liver, heart, kidneys, spleen, lungs, tongue, rumen, omasum, abomasum, small intestine, large intestine, mesentery, intern fat, clipping and tail were grouped, processed and completely homogenized in a 65-L Cutter, from where a sample representing organs and guts of the animals was taken.

To represent each treatment, two animals from each treatment were randomly chosen, from which samples of head, fore and hind limbs were taken for physical separation and further analyses of soft tissue, bones and leather.

Carcass of each animal was divided into two halves, then weighed and cooled in a cold chamber at $-2.5^{\circ} \mathrm{C}$ for 24 hours.

Left half-carcasses were dissected, followed by separation of muscles, fat and bones, which were weighed and sampled.

Muscular tissue and adipose tissue were milled and bone tissue was sawn into smaller parts. A representative sample was taken from each component for direct determination of contents of carcass protein, fat and minerals.

Samples of blood, leather, organs and guts and feet physical components, head and carcasses were frozen and then processed according to procedure described by Paulino et al. (2004), for obtaining fat dry matter and then predefatted dry matter.

Afterwards, all samples were processed in a ball mill and send to further quantifications of total nitrogen, ether extract and macrominerals ( $\mathrm{Ca}, \mathrm{P}, \mathrm{Na}$ and $\mathrm{Mg}$ ), according to recommendations by Silva \& Queiroz (2002). Protein content was obtained by the product between total nitrogen content and factor 5.88, as suggested by Baldwin (1995).

The fat removed at pre-defattening was calculated by the difference between fat dry matter and pre-defatted dry matter, whose result was added to the one obtained for residual ether extract in pre-defatted dry matter, for quantification of total fat content.

Mineral solution for determination of mineral microelements was prepared by nitro-perchloric digestion. After proper dilutions, P content was estimated by colorimetry, and contents of $\mathrm{Ca}$ and $\mathrm{Mg}$ were estimated by atomic absorption spectrophotometer and contents of $\mathrm{Na}$ were estimated by flame spectrophotometer.

Contents of protein, fat and mineral in the empty body were determined in function of percentage concentrations in samples of body constituents and weight of those components.

Content of body energy was obtained from contents of protein and fat in the empty body and its respective caloric equivalents, according to the equation proposed by ARC (1980):

$\mathrm{EC}=5.6405 \mathrm{X}+9.3929 \mathrm{Y}$

in which: $\mathrm{EC}=$ energy content (Mcal); $\mathrm{X}$ = body protein (kg); Y = body fat (kg).

To estimate net energy requirements for weight gain for animals with different empty body weight gains and for different ranges of empty body weight, a relationship between retained energy (RE) in function of the metabolic EBW and EBWG was obtained, as suggest by NRC (2000): $\mathrm{RE}_{(\text {Mcal/day })}=\mathrm{a} \cdot \mathrm{EBW}^{0.75}$. $\mathrm{EBGW}^{\mathrm{b}}$

Requirement of net protein for gain was obtained by multiple linear regression of retained protein ( $R P, g /$ day) in function of EBWG (kg/day) and retained energy (RE, Mcal/day), according to the equation:

$\mathrm{RP}_{(\mathrm{kg} / \mathrm{day})}=\mathrm{EBWGx}(\mathrm{a}+\mathrm{b} \times \mathrm{RE} / \mathrm{EBWG})$

Contents of macrominerals (Ca, $\mathrm{P}, \mathrm{Na}$ and $\mathrm{Mg}$ ) retained in the body of the animals of each treatment, and for all the treatments together, were estimated by regression equations of the content of those minerals in the body of the animals (kg), in function of their EBW, as follows:

Mineral $_{(\mathrm{kg})}=\mathrm{a} \times \mathrm{EBW}^{\mathrm{b}}$

By deriving prediction equations of body macromineral content in function of EBW, the prediction equation of macromineral content per kg of EBW gain was obtained, which corresponds to the net requirements of the mineral for 1.0-kg gain of EBW. Those requirements were obtained from equations as follows:

Mineral $_{(\mathrm{kg} / \mathrm{kgEBW})}=\mathrm{a} \times \mathrm{b} \times \mathrm{EBWi}^{(\mathrm{b}-1)}$

All regressions were developed by using PROC NLIN of SAS (Statistical Analyses System, version 9.0). The initial values of the parameters were obtained from literature data.

Outliers were tested by evaluation of studentized residues in relation to values predicted by the model. Data were removed when studentized residues were outside the range from -2.5 to 2.5 . 
For calculation of parameters of prediction equation of nutritional requirements, data of animals with negative weight gain of empty body were removed due to variations in the efficiency of use of nutrient metabolized by the body.

Comparison of the models between supplementation systems (mineral salt or concentrate) and genders (castrated and non-castrated) was carried out according to test of models identity suggested by Regazzi (2003). However, the "F" test was used for their comparisons.

Significance level of $5 \%$ was used in all statistical analyses.

\section{Results and Discussion}

The average EBW:BW ratio observed in this study was 0.901 , which is very close to that observed by Valadares Filho et al. (2010) for confined animals (0.895), but diverging from the relationship observed by these authors for animals on pasture (0.863).

Castration or concentrate supplementation of animals in this experiment were not able to affect their energy requirements for weight gain (Table 2). This result is compatible with a greater development of protein-rich body components of animals reared on pastures, in conditions similar to the ones observed in this research (Fernandes, 2009). According to this author, low energy density of the diets of animals in pastures tends to prioritize protein growth, leading to few variations in the energy content of weight gain.

This effect seemed to be able to neutralize the greater body fat deposition capacity of castrated animals and also those with higher energy ingestion (supplemented with concentrate).
The amount of protein retained in the gain (protein net requirement for gain) also was not different for animals fed with or without concentrate supplementation..

Coefficients fitted for prediction equations of energy requirements of animals supplemented with concentrate, for both evaluated genders, and even for a joint equation presented similar behavior in relation to the one normally observed in the literature (Almeida et al., 2009).

In the protein requirement prediction equation, "a" coefficient shows the effect of daily weight gain level on protein retention, and it is generally positive, whereas " $b$ " coefficient is associated to energy content of animal gain.

Usually, "b" coefficient tends to be negative, reflecting normal animal growth behavior (NRC, 2000; Chizzotti et al., 2008; Valadares Filho et al., 2010): as gain energy content increased, fat proportion increased, whereas protein proportion in this gain reduced.

The results obtained in this study (positive "b" coefficients) might be associated with different composition of weight gain of animals in pasture. Fernandes (2009) showed that animals in this condition of production continue to increase the proportion of protein present in the gain as the energy density of this gain increases. This increase in protein content during gain occurred parallel to fat proportion increase and to a reduction in water content during gain. That author associated this effect to the small energy concentration of diets of animals on pasture, even when they were fed concentrate supplementation.

Among all equations adjusted to estimate mineral content in weight gain (Table 3), only requirements of calcium presented differences between castrated and noncastrated animals.

Those coefficients show that non-castrated males have a body $\mathrm{Ca}$ accumulation rate sharper than the castrated

Table 2 - Parameters of the equations and comparison of the models for energy and protein requirement prediction for gain

\begin{tabular}{|c|c|c|c|}
\hline \multirow[t]{2}{*}{ Groups } & \multicolumn{2}{|c|}{ Parameters $^{1}$} & \multirow[t]{2}{*}{$\mathrm{P}$ value for model comparisons } \\
\hline & a & $\mathrm{b}$ & \\
\hline \multicolumn{4}{|l|}{ Energy } \\
\hline Supplemented & 0.0459 & 0.7190 & \\
\hline Castrated & 0.0624 & 1.0459 & 0.114 \\
\hline Non-castrated & 0.0278 & 0.4181 & \\
\hline Without supplementation & 79.4 & 16.2 & 0.480 \\
\hline Supplemented & 0.307 & 30.2 & \\
\hline Castrated & 65.1 & 15.2 & 0.617 \\
\hline Non-castrated & 21.9 & 36.5 & \\
\hline Set & 40.7 & 23.6 & \\
\hline
\end{tabular}


Table 3 - Equation parameters and comparison of models for nutritional mineral requirement prediction for gain

\begin{tabular}{|c|c|c|c|}
\hline \multirow[t]{2}{*}{ Groups } & \multicolumn{2}{|c|}{ Parameters $^{1}$} & \multirow[t]{2}{*}{$\mathrm{P}$ value for model comparisons } \\
\hline & a & B & \\
\hline \multicolumn{4}{|l|}{ Calcium } \\
\hline Supplemented & 0.1319 & 0.6546 & \\
\hline Castrated & 0.1134 & 0.6818 & 0.014 \\
\hline Non-castrated & 0.0205 & 1.0116 & \\
\hline \multicolumn{4}{|c|}{ Phosphorus } \\
\hline Without supplementation & 0.0084 & 0.9980 & 0.204 \\
\hline Supplemented & 0.0409 & 0.7042 & \\
\hline Castrated & 0.0187 & 0.8482 & 0.176 \\
\hline Non-castrated & 0.0128 & 0.9324 & \\
\hline Set & 0.0104 & 0.9053 & \\
\hline \multicolumn{4}{|c|}{ Sodium } \\
\hline Non-castrated & 0.0015 & 1.0386 & \\
\hline Set & 0.0013 & 1.0643 & \\
\hline \multicolumn{4}{|c|}{ Magnesium } \\
\hline Without supplementation & 0.0015 & 0.7726 & 0.852 \\
\hline Supplemented & 0.0039 & 0.5980 & \\
\hline Castrated & 0.0073 & 0.4834 & 0.343 \\
\hline Non-castrated & 0.0008 & 0.8929 & \\
\hline Set & 0.0023 & 0.6948 & \\
\hline
\end{tabular}

animals. This may be associated to a greater bone growth of those animals. This hypothesis is reinforced by the fact that non-castrated animals tend to have a later maturity, which prolongs muscular growth and also may cause a longer bone growth in these animals (Berg \& Butterfiled, 1976).

Also, the greater non-castrated male muscular growth might have led to a greater Ca deposition inasmuch as those tissues are also Ca-rich. However, based on gain protein requirement data, data from this experiment do not seem to have shown this greater muscular growth in these animals. For all the other minerals, and even when Ca requirements of animals in different supplementation systems were compared, gender or supplementation did not affect the content of those minerals in weight gain.

The energy requirement estimated in this experiment (Table 4) were similar to those suggested by Valadares Filho et al. (2010) for confined castrated males, but they were about $20 \%$ superior to the recommendations of those authors for grazing males, castrated or non-castrated.

This result is directly linked to the weight gain composition of the animals, and it may be influenced by other factors, besides the fact that the animals are producing on pastures

As an example of this variability of result, Freitas et al. (2006) obtained estimates of net energy for weight gain, which varied by approximately $7 \%$ above the estimates observed in this study, up to about $13 \%$ below them.

Estimate protein requirement behaved differently from the predicted by Valadares Filho et al. (2010). Those authors observed a decrease in protein retained during weight gain as the animal increases its body weight. In this experiment, the behavior was opposite, since the values estimated remained below the ones predicted by those authors until animals reached around $300 \mathrm{~kg} \mathrm{BW}$, inverting this behavior from this weight. This protein requirement behavior is consistent with the greater protein content in weight gains with greater energy density, which was previously discussed.

Because bigger animals tend to have greater gain energy density, in the equations proposed by Valadares

Table 4 - Energy, protein and mineral net requirements for 1.0-kg gain of empty body weight

\begin{tabular}{lcrcrr}
\hline Body & \multicolumn{5}{c}{ Net energy } \\
\cline { 2 - 6 } weight & Energy, Mcal & Protein, g & P, g & Na, g & Mg, g \\
\hline 200 & 2.92 & 110 & 5.70 & 1.95 & 0.317 \\
250 & 3.46 & 122 & 5.58 & 1.97 & 0.296 \\
300 & 3.96 & 134 & 5.49 & 2.00 & 0.280 \\
350 & 4.45 & 146 & 5.41 & 2.02 & 0.267 \\
400 & 4.92 & 157 & 5.34 & 2.03 & 0.257 \\
450 & 5.37 & 167 & 5.28 & 2.05 & 0.248 \\
\hline
\end{tabular}


Filho et al. (2010), the lower protein requirement of animals with greater body weight may be associated to a lower protein requirement in these greater energy density weight gains. In this experiment, weight of animals increased (gain energy content) along with protein requirement.

Phosphorus requirements varied from -11 to $+4 \%$ from those predicted by Valadares Filho et al. (2010). On the other hand, sodium presented results which varied in similar estimates up to estimates $20 \%$ below what had been predicted by those authors. Finally, recommendations of $\mathrm{Mg}$ for gain observed in this study were above the ones predicted in that system. Levels of $\mathrm{Mg}$ predicted in this study for $1.0-\mathrm{kg} /$ day gain allowed a weight gain above $1.5 \mathrm{~kg} /$ day, according to that system.

Requirements of Ca estimated for non-castrated animals (Table 5), are above those predicted by Valadares Filho et al. (2010). The requirements observed in this research can be twice as much the one predicted by those authors. Contrarily, the requirements estimated for castrated animals are within the same range as the suggestions of those authors.

Table 5 - Calcium net requirement for 1.0-kg/EBW gain

\begin{tabular}{cc}
\hline Body weight & Ca, g \\
\hline & Castrated \\
200 & 14.3 \\
300 & 13.3 \\
350 & 12.6 \\
400 & 12.0 \\
450 & 11.5 \\
& 11.1 \\
200 & \\
250 & Non-castrated \\
300 & 22.1 \\
350 & 22.1 \\
400 & 22.2 \\
450 & 22.2 \\
\hline
\end{tabular}

EBW - empty body weight.

\section{Conclusions}

Castration or concentrate supplementation does not affect requirements for weight gain, except requirements of Ca, which were higher than for non-castrated animals. The suggested nutritional requirement prediction equations for weight gain are:

Retained energy, Mcal/day $=0.0600 \times \mathrm{EBWi}^{0.75} \times$ EBWG ${ }^{1.0783}$,

Retained protein, $\mathrm{kg} /$ day $=\mathrm{EBWGx}(40.7+23.6 \times \mathrm{RE} /$ EBWG),

Minerals, kg/kg EBW :

$$
\begin{aligned}
\mathrm{Ca} & =0.1134 \times 0.6818 \times \mathrm{EBWi}^{(0.6818-1)}(\text { castrated }) \\
& =0.0205 \times 1.0116 \times \mathrm{EBWi}^{(1.0116-1)}(\text { non-castrated }) \\
\mathrm{P}= & 0.0104 \times 0.9053 \times \mathrm{EBWi}^{(0.9053-1)} ; \\
\mathrm{Na} & =0.0013 \times 1.0643 \times \mathrm{EBWi}^{(1.0643-1)} ; \\
\mathrm{Mg} & =0.0023 \times 0.6948 \times \mathrm{EBWi}^{(0.6948-1)} .
\end{aligned}
$$

\section{References}

AGRICULTURAL RESEARCH COUNCIL - ARC. The nutrient requirements of ruminants livestock. London: 1980. 351p.

ALMEIDA, V.V.S.; QUEIROZ, A.C.; SILVA, R.R. et al. Body composition and net and dietary macrominerals requirements of Nellore steers under grazing. Revista Brasileira de Zootecnia, v.38, p.1081-1087, 2009.

BALDWIN, R.L. Modeling ruminant digestion and metabolism. London: Chapman \& Hall, 1995. 592p.

BERG, R.T.; BUTTERFIELD, R.M. New concepts of cattle growth. Sydney: Sydney University Press, 1976. 240p.

CHIZZOTTI, M.L.; TEDESCHI, L.O.; VALDARES FILHO, S.C. A meta-analysis of energy and protein requirements for maintenance and growth of Nellore Cattle. Journal of Animal Science, v.86, n.7, p.1588-1597, 2008.

FERNANDES, H.J. Estudo do crescimento de tourinhos em pastejo recebendo suplementação concentrada com diferentes perfis protéicos. 2009. 288f. Tese (Doutorado em Zootecnia) - Universidade Federal de Viçosa, Viçosa-MG.

FONTES, C.A.A. Composição corporal, exigências líquidas de nutrientes para ganho de peso e desempenho produtivo de animais zebuínos e mestiços europeu-zebu. Resultados experimentais. In: SIMPÓSIO INTERNACIONAL SOBRE EXIGÊNCIAS NUTRICIONAIS DE RUMINANTES, 1., 1995, Viçosa, MG. Anais... Viçosa, MG: Universidade Federal de Viçosa, 1995. p.419-455.

FREGADOLLI, F.L. Composição corporal e exigências nutricionais de novilhos de três grupos genéticos em pastejo. 2005. 85f. Tese (Doutorado em Zootecnia) Universidade Estadual Paulista, Faculdade de Ciências Agrárias e Veterinárias, Jaboticabal.

FREITAS, J.A.F.; QUEIROZ, A.C.; DUTRA, A.R. et al. Composição do ganho e exigências de energia e proteína para ganho de peso em bovinos Nelore puros e mestiços. Revista Brasileira de Zootecnia, v.35, n.3, p.886-893, 2006.

LOFGREEN, G.P.; GARRETT, W.N.A. System for expressing net energy requeriments and feed values for growing and finishing beef cattle. Journal of Animal Science, v.27, n.3, p.793-806, 1968.

MORAES, E.H.B.K.; PAULINO, M.F.; MORAES, K.A.K. et al. Exigências de proteína de bovinos anelorados em pastejo. Revista Brasileira de Zootecnia, v.39, n.3, p.601-607, 2010.

NATIONAL RESEARCH COUNCIL - NRC. Nutrient requirements of beef cattle. 7.ed. Washington, D.C.: National Academic Press, 2000. 242p.

PAULINO, P.V.R.; COSTA, M.A.; VALADARES FILHO, S.C. et al. Exigências nutricionais de zebuínos: Minerais. Revista Brasileira de Zootecnia, v.33, n.3, p.770-780, 2004.

PAULINO, M.F.; FONTES, C.A.A.; JORGE, A.M. et al. Composição corporal e exigências de macroelementos minerais (Ca, P, Mg, Na e K) de bovinos não-castrados de quatro raças zebuínas. Revista Brasileira de Zootecnia, v.28, n.3, p.634-641, 1999.

REGAZZI, A.J. Teste para verificar a igualdade de parâmetros e a identidade de modelos de regressão não-linear. Revista Ceres, v.50, p.9-26, 2003. 
SILVA, D.J.; QUEIROZ, A.C. Análise de alimentos (métodos químicos e biológicos). Viçosa, MG: Universidade Federal de Viçosa, 2002. 235p.

TEDESCHI, L.O.; BOIN, C.; FOX, D.G. et al. Energy requirement for maintenance and growth of Nellore bulls and steers fed high-forage diets. Journal of Animal Science, v.80, n.6, p.1671-1682, 2002.
VALADARES FILHO, S.C.; MARCONDES, M.I.; CHIZZOTTI, M.L. et al. Exigências nutricionais de zebuínos puros e cruzados - BR CORTE. 2.ed. Viçosa, MG: UFV, DZO, 2010. 193p.

ZERVOUDAKIS, J.T.; PAULINO, M.F.; DETMANN, E. et al. Conteúdo corporal e exigências líquidas de proteína e energia de novilhos suplementados no período das águas. Revista Brasileira de Zootecnia, v.31, n.1, p.530-537, 2002. 